ARTICLE

\title{
Isolation, Characterization and Antibiotic Susceptibility Pattern of Escherichia coli from Diarrhoeic Lambs in Sokoto, Northwestern Nigeria
}

\author{
AHMED', A., EGWU ${ }^{2}$, G. O., GARBA ${ }^{3}$, H. S. and MAGAJI ${ }^{4}$, A. A. \\ ${ }^{1}$ National Veterinary Research Institute, Zonal Research Laboratory, Birnin Kebbi; ${ }^{2}$ Dept of Veterinary Medicine, University of Maiduguri; \\ ${ }^{3}$ Department of Veterinary Medicine, Surgery \& Theriogenology; ${ }^{4}$ Department of Veterinary Public Health and Animal Production, \\ Usumanu Danfodiyo University, Sokoto. Corresponding author: abdahmed65@gmail.com. Tel: 234 (0) 8061568106
}

\section{SUMMARY \\ A total of 127 faecal samples were collected from diarrhoeic lambs and examined for Escherichia coli. The bacterial culture involved pre-enrichment in peptone water before incubation at $37^{\prime}$ for 24 hours. Out of the isolates obtained, $42(36.84 \%)$ were positive for Escherichia coli. Characterization of the isolates revealed serotypes 0157 (13), $0118(9), 0111(8), 026(7)$, and $0103(5)$ as the most frequent strains. Their prevalence rates being $31.0 \%$, $21.4 \%, 19.0 \%, 16.7 \%$ and $11.9 \%$ respectively. Minimum Inhibitory Concentration (MICS) of the $E$ coli strains to six antibiotics revealed tetracycline as having the lowest MIC, which ranged from $3.12 \mathrm{\mu g} / \mathrm{ml}-50 \mathrm{\mu g} / \mathrm{ml}$ followed by chloramphenicol with an MIC ranging between $6.25 \mathrm{pg} / \mathrm{ml}$ - $100 \mathrm{pg} / \mathrm{ml}$. It was concluded that there was need for further research to study the pathogenicity of the $E$ coli strains and that resistance to antibiotics was a problem which might have resulted from indiscriminate use of these drugs. \\ KEYWORDS: Isolation, Characterization, Antibiotic susceptibility, Ecoli, Lambs}

\section{INTRODUCTION}

Escherichia coli, an important bacterial species, belonging to the family Enterobacteriaceae, is the most frequently encountered microorganism in the food industry. Its presence has also been detected in soil, plants, and animal feces and in water where it could serve as one of the factors affecting human and animal health (Arshad et al., 2006; Smith et al., 2009). Epidemiological studies on diarrhoea in lambs by Snodgrass (1978), Ansari et al. (1978) and Ahmed (2009) have shown that $E$. coli is thought to be an important cause of neonatal lamb diarrhoea as well as mortality. E. coli has been associated with
2 forms of enteric and septicemic infections, with the enteric form being more commonly observed in 2 - 8 day old lambs and the septicemic form in lambs at $2-6$ weeks of age. The detection and accurate identification of $E$. coli is therefore, enormously important. Diarrhoea resulting from $E$. coli infection is treated using fluid administration as the mainstay of therapy (Williamson, 2002; van Aardt, 2003; Schoenian, 2006) although broad spectrum antibiotics are also used for both treatment and prevention of $E$. coli scours in lambs and calves to minimize losses (Novotna et al., 2005; Schoenian, 2006; Nasr and Meghawary, 2007). The problem of drug resistance in modern veterinary medicine is increasingly receiving close attention. It is therefore imperative in clinical practice to recognize the need to use drugs that are effective in treating the particular problem at hand effectively while at the same time avoiding using those that can result in resistance. However, besides having clinical consequences, resistant E. coli strains of animal origin may be the source of determinants of resistance for possible transfer to human strains. The aim of this study was to isolate $E$. coli from diarrhoeic lambs and characterize the isolates to determine the strains involved. Also to investigate the susceptibility (Minimum Inhibitory Concentration- MIC) of the strains to a variety of commonly used antibiotics in the study area.

\section{MATERIALS AND METHODS}

The study was conducted in Sokoto, the capital of Sokoto state, located in the north western part of Nigeria over one year period (November, 2006 - October, 2007). Ten sheep flocks were randomly selected. Total sheep population in the flocks was 624 out of which 246 were lambs. All 
animals were reared under semi intensive system with some varying form of supplementation. Fecal samples were collected from 127 lambs that were diarrhoeic during period of study. Samples were collected in polythene bags and then placed in cool box and transported to the Microbiology Laboratory of the School of Medical Laboratory Sciences, Usmanu Danfodiyo University Teaching Hospital for processing.

\section{Culture and identification of E. coli}

Feacal specimens obtained from the lambs were directly cultured on eosin methelylene blue, EMB (Oxoid, UK) agar plates. After incubation at $37^{\circ} \mathrm{C}$ for $24 \mathrm{hr}$, those colonies with dark bluish green colour or those possessing dark centres and have transparent colourless peripheries were restreaked on EMB or sheep blood agar plates and incubated. Three to five with distinct morphology were then obtained in pure culture and identified as E. coli based on Grams stain, oxidase, catalase tests and other biochemical tests as described by Quinn and Markey, (2003).

\section{Serotyping of E. coli}

Serotyping of $O$ antigen of $E$. coli was carried out using available $\mathrm{O}$ antigen containing $E$. coli antisera (Oxoid). $2 \mathrm{ml}$ of commercially prepared polyclonal E. coli antisera of serotypes $\mathrm{O} 26$, O118, O111, O157 and 0103 sourced from Department of Agriculture and Veterinary Sciences, Queens University, Belfast, UK were used. Each antiserum was diluted according to the manufacturer's recommendation. A slide agglutination test was then used to identify each serotype and positive result was recorded. This was done as described by Quinn and Markey (2003).

\section{Antibiotic Susceptibility studies}

The MIC of six antimicrobials agents commonly available (ampicillin, doxacyclin, penicillin G benzathine, ciprofloxacin, chloramphenicol and tetracycline) were determined using the macro broth dilution method as described by NCCLS (2002) and Latiha (2004). These were selected because they constitute some of the commonly used chemotherapeutic antimicrobial agents in the area. The MIC of each drug was the lowest concentration of the drug required to inhibit visible growth of the tested organism.

\section{RESULTS}

Out of the 127 fecal samples from which 114 bacterial pathogens were isolated, E. coli was the most significant $(\mathrm{P}<0.05)$ numbering 42 (36.84\%). Table I depicts the result of the agglutination test in which all the 42 isolates agglutinated with $E$. coli antisera tested. From the 42 isolates serotyped, the following strains were identified with their respective prevalence as $\mathrm{O} 157$ (13), O118 (9), O111 (8), O26 (7) and 0103 (5). Their respective prevalence rates being $31.0 \%, 21.4 \%, 19.0 \%, 16.7 \%$ and $11.9 \%$ in that order.

The MIC of the six tested antibiotics against $E$. coli serotypes is presented in Table II. The MIC ranged from $3.12 \mu \mathrm{g} / \mathrm{ml}->100 \mu \mathrm{g} / \mathrm{ml}$. The MIC for penicillin ranged from $12.5 \mu \mathrm{g} / \mathrm{ml}-50 \mu \mathrm{g} / \mathrm{ml}$ while ampicillin had MIC ranging between 12.5 $>100 \mu \mathrm{g} / \mathrm{ml}$. The MIC for tetracycline was from $3.12 \mu \mathrm{g}-50 \mu \mathrm{g} / \mathrm{ml}$. Doxacyclin had MIC of $25 \mu \mathrm{g} / \mathrm{ml}->100 \mu \mathrm{g} / \mathrm{ml}$. The MIC values for chloramphenicol and ciprofloxacin were $6.25 \mu \mathrm{g} / \mathrm{ml}-100 \mu \mathrm{g} / \mathrm{ml}$ and $25 \mu \mathrm{g} / \mathrm{ml}-100 \mu \mathrm{g} / \mathrm{ml}$ respectively.

Table I: Characterization of E. coli isolated from diarrheic lambs

\begin{tabular}{|lcl|}
\hline E. coli serotype & Number & \% strain \\
\hline \hline O26 & 7 & $(16.7)$ \\
0118 & 9 & $(21.4)$ \\
0111 & 8 & $(19.0)$ \\
0157 & 13 & $(31.0)$ \\
0103 & 5 & $(11.9)$ \\
Total & 42 & $(100.0)$ \\
\hline
\end{tabular}

Figures in brackets are percentages of total isolations

Table II: Antibiotic susceptibility (MIC) values of E. coli isolates from diarrhoeic lambs.

\begin{tabular}{|l|c|c|c|c|l|l|}
\hline \multirow{2}{*}{ E. coli (serotype) } & \multicolumn{7}{|c|}{ MIC values in $\mu \mathrm{g} / \mathrm{ml}$} \\
\cline { 2 - 7 } & Pen & Amp & Tetr & Dox & Chl & Cipr \\
\hline $0157(n=13)$ & 50 & 12.5 & 25 & 25 & 6.25 & 100 \\
$026(n=6)$ & 50 & 100 & 50 & $>100$ & 50 & 25 \\
$0111(n=8)$ & 12.5 & $>100$ & 25 & 50 & 6.25 & 50 \\
$0103(n=5)$ & 25 & 12.5 & 6.5 & 50 & 100 & 50 \\
$0118(n=11)$ & 50 & 50 & 3.12 & 25 & 6.25 & 100 s \\
\hline
\end{tabular}

Range $3.12 \mu \mathrm{g} / \mathrm{ml}->100 \mu \mathrm{g} / \mathrm{ml}$

Pen=penicillin, Amp=ampicillin, Tetr=tetracycline, Dox=doxacyclin, $\mathrm{Chl}=$ chloramphenicol, $\mathrm{Cipr}=$ ciprofloxacin

\section{DISCUSSION}

In the present study, a total of $42(36.84 \%)$ E. coli isolates were obtained from fecal samples of 
lambs that had diarrhoea. Similar results have been reported by Ansari et al. (1978); Arshad et al. (2006) and Smith et al. (2009). E. coli is known as a common cause of diarrhoea in young ruminants (Novotna et al., 2005; Nasr and Meghawery, 2007; Schoenian, 2008) and in humans (Acha et al., 2004; Smith et al., 2009). Although $51.6 \%$ of the lambs examined in the study suffered from diarrhoea, the result obtained do not allow the conclusion that the diarrhoea was caused by $E$. coli. Such conclusion would only be possible if other parasitic, viral or bacterial agents are excluded.

The present study revealed strains O157, O118, O111, $\mathrm{O} 26$ and $\mathrm{O} 103$ to be the most prevalent serotypes. This result agrees with the observations of Mamza et al. (2008) who reported similar serotypes from cattle feaces and dairy products in Adamawa and Borno states. The result is however in variance with the observations of Sharif et al. (2005) and Novotna et al. (2005) in Jordan as well as of Blanco et al. (1996) in Spain. In both studies, O118, O111, O105 were not isolated. In Japan, Kodaka et al. (2004) reported the isolations of serotypes O157, O26, and 0111 in children suffering bacterial enteritis. The relatively frequent occurrence of serotype 0157 among sheep and goats products (Novotna et al., 2005) suggests that this strain may be a relatively important source of infection for humans. This could particularly be true in areas where people come into contact with sheep flocks especially in local animals markets.

The MIC values showed that the least resistance was exhibited against tetracycline which had the lowest MIC value $(3.12 \mu \mathrm{g} / \mathrm{ml})$. This result is lower than $10 \mu \mathrm{g} / \mathrm{ml}$ reported by Nwanze et al. (2007) for tetracycline. However, with a lower cut-off point of $3.12 \mu \mathrm{g} / \mathrm{ml}$, it clearly indicates that this antibiotic is effective at this concentration. Chloramphenicol had MIC of $6.25 \mu \mathrm{g} / \mathrm{ml}$. According to Theodore, (2007), chloramphenicol appears to be more effective against Gram positive organisms. However, its effectiveness in treating Gram negative organisms has been reported (NCCLS, 2002; Poole, 2003). Moderate resistance was shown to penicillin and ampicillin. This result corroborates the findings of Cid et al. (1996) and Orden et al. (2000). According to Abiade-Paui et al. (2003), the frequent use of these drugs in veterinary practice in Nigeria may be responsible for their resistance. Alternatively, the frequent use of antibiotics in food animals for chemotherapy, prophylaxis and to enhance growth could have accounted for resistance.

E. coli strains were most resistant to ciprofloxacin and doxacyclin which had the highest MICs in the present study. This result is not in agreement with the report of Theodore (2007). The testing of other Gram negative bacteria that showed less resistance in the previous study might have accounted for the difference.

It was concluded from this study that the problem of continuous re-infection in young lambs particularly in dirty environments where these young lambs are kept can be a major concern. The possibility of $E$. coli infection in humans handling these young animals can also be of public health significance. Further characterization of $E$. coli strains in lambs including their pathogenicity as well as serotyping studies need to be undertaken. Also, it is apparent that resistance to antibiotics may be due to indiscriminate use. There is the need to constantly monitor the susceptibility pattern of bacterial pathogens to commonly used antibiotics for effective treatment of such important neonatal diseases.

\section{AKNOWLEDGEMENT}

The authors wish to thank the Director of the School of Medical Laboratory Sciences, Usmanu Danfodiyo University, Sokoto as well as Mal. Kabir Garba, Chief Laboratory Technologist, for allowing the work to be undertaken in their laboratory and for the use of facilities at the microbiology laboratory.

\section{REFERENCES}

ABIADE-PAUI, C. U., KENE, L. C. and ACHA, K. F. (2003): Antibiogram and antibiotic susceptibility of salmonellae from effluent from Nsukka municipal abattoir. Nig. Vet. J. 24(3): 103-106.

ACHA, S. J., KUHN, I., JONSSON, P., MBAZIMA, G., KATOULI, M. (2004): Studies on calf diarrhoea in Mozambique: Prevelance of bacterial pathogens. Acta vet. scand. 45, 27-36.

AHMED, A. (2009): Epidemiological studies on some causes of lamb mortality in Sokoto state. $P h D$. 
Thesis. Usmanu Danfodiyo University, Sokoto. 198.

ANSARI, M. M., RENSHAW, H. W. and GATES, N. L. (1978): Collibacillosis in neonatal lambs: Onset of diarrheal disease and isolation and characterization of enterotoxigenic Escherichia coli from enteric and septicemic forms of the disease. Am. J. Vet. Res., 33(1): 11-14

ARSHAD, R., FAROOQ, S. and SHAHID-ALI, S. (2006): Manipulation of different media and methods for cost- effective characterization of Escherichia coli strains collected from different habitats. Pak. J. Bot., 38(3): 779-789.

BLANCO, J., DOLORES, C., JESUS, E. B., BLANCO, M., QUITEIRA, J. R. S. and DE LA FUENTE, R. (1996): Serogroups, toxins and antibiotic resistance of Escherichia coli strains isolated from diarrhoeic lambs in Spain. Veterinary Microbiology, 49(3-4): 209-217.

CID, D., QUITEIRA, J. R. S., VALLE, J., VADILLO, S. and DE LA FUENTE, R. (1996): In vitro susceptibility of Escherichia coli strains isolated from diarrhoeic lambs and goats kids to 14 antimicrobial agents. J. of Vet. Pharm and Therapeutics, 19(5): 397-401.

KODAKA, H., UESAKA, Y. and KASHITAN, F. (2004): Nissui Glucose fermentative Gram-negative rod identification system EB-20 gives a unique profile for typical non-sorbitol-fermenting Escherichia coli O157:H7. Journal of Clinical Microbiology, 42(1): 354-358.

LATIHA, M. K. (2004): Manual on Antimicrobial Susceptibility Testing. Under the auspices of the Indian Association of Medical Microbiologists. Christian Medical College, Vellore, Tamil Nadu, India. Pp 35.

MAMZA, S. A., EGWU, G. O., MSHELIA, G.D. and GULANI, I. (2008): Beta- 1 a c t a m a s e s : A paradigm of Nigerian avian isolates of Escherichia coli (E. coli) and Staphylococcus aureus (S. aureus) and their global health implications (In press).

NASR, E. M. and MEGHAWERY, M. A. (2007): Studies on diarrhoea in calves with emphasis on the role of Clostridium perfringes and Escherichia coli. Res. J. Anim. and Vet. Sci, 2:28-33.

NOVOTNA, R., ALEXA, P., HAMRIK, J., MADANAT, A., SMOLA, J. and CIZEK, A. (2005): Isolation and characterization shiga toxin-producing Escherichia coli from sheep and goats in Jordan with evidence of multiresistent serotype O157:H7. Vet. Med-Czech, 50, 2005(3):111-118.

NATIONAL COMMITTEE FOR CLINICAL LABORATORY STANDARDS (2002):
Performance standards for antimicrobial disc and dilution susceptibility tests for bacteria isolated from animals. 22:13-14.

NWANZE, P. L., NWARU, L. M., ORANUSI, S., DIMKPA, U., OKWU, M. U., BABATUNDE, B. B., ANAKE, T. A., JATTO, W. and ASAGWARA, C. E. (2007): Urinary tract infection in Okada village: Prevalence and antimicrobial susceptibility pattern. Scientific Research and Essay, 2(4), 112116.

ORDEN, J. A., QUITERIA, J. R. S., GARCIA, S., CID, D. and DE LA FUENTE, R. (2000): In vitro susceptibility of Escherichia coli strains isolated from diarrhoeic dairy calves to 15 antimicrobial agents. J. Vet. Med. B Infect Dis Vet Public Health. 47(5):329-35.

POOLE, K. (2003): Overcoming multidrug resistance in Gram negative bacteria. Currrent Opinion Investigating Drugs, 4:128-139.

QUINN, B. G. and MARKEY, B. K. (2003): Concise Review of Veterinary Microbiology.Blackwell Publ. Ltd. Oxford. Pp153.

SCHOENIAN, S. (2006): Diarrhoea (scours) in small ruminants. In: Small Ruminant Fact Sheet Series. University of Maryland Cooperative Extension. $1-4$

SHARIF, L., OBEIDAT, J. and AL-ANI, F. (2005): Risk factors for lamb and kid mortality in sheep and goat farms in Jordan. Bulgarian Vet. J., 76:445447.

SMITH, S. I., BELLO, O. S., GOODLUCK, H. A., OMONIGBEHIN, E. A., AGBOGU, V. N. and ODEIGAH, P. (2009): Prevalence of EHEC O157:H7 from human and environmental samples from Lagos and Zaria. Pak J Med Sci 25 (3):398-403

SNODGRASS, D. R. (1978): Diarrhoea in neonatal lambs. In: The management and diseases of sheep; Paper presented at British Council Special Courses, Edinburgh, $5^{\text {th }}-17^{\text {th }}$ March, 1978.

THEODORE, M. (2007): Prevalence and Antibiogram of Urinary Tract Infection among prison inmates in Nigeria. The Internet Journal of Microbiology, 3(2): 1-9.

VAN AARDT, M. P. (2003): Lamb mortality. Animal Diseases 23. Elsenburgh/Sprinbok Vet. Services. 13.http://www.elsenburgh.com/info/els/095/095 e.html.

WILLIAMSON, L. (2002): Young ruminant diarrhoea. In: AMS 5350 Large Animal Digestive System. http://Iam.vet.edu/LAM/LM000154.HTML . pp 1-7. (Accessed 23/8/2009). 